\title{
The kidney of late preterm infants
}

\author{
Vassilios Fanos ${ }^{1 *}$, Clara Gerosa ${ }^{2}$, Claudia Fanni ${ }^{1}$, Cristina Loddo ${ }^{1}$, Melania Puddu', Giovanni Ottonello ${ }^{1}$, Gavino Faa ${ }^{2}$ \\ From XX National Congress of the Italian Society of Neonatology \\ Rome, Italy. 9-11 October 2014
}

\section{Introduction}

The risk of morbidity in late preterm neonates varies greatly depending on gestational age: it is 1 out of 2 at 34 weeks, 1 out of 4 at 35 weeks and 1 out of 10 at 36 weeks. Very little is known about the renal pathology of these infants.

\section{Nephrogenesis in the late preterm}

The process of nephron formation ceases between 34 and 36 weeks of gestation [1], the limit within which the term late preterm is applied.

In 1943, Potter and Thierstein examined the autopsies of 1000 fetuses and neonates and found the presence of the nephrogenic zone in $100 \%$ of 30 -week fetuses, in about $80 \%$ of 34 -week cases and in $30 \%$ of 36 -week cases. They stated that in most of these neonates nephrogenesis had ceased at 35 weeks [2].

In 2008, Ferraz et al., on applying immunohistochemistry to the kidneys of 86 fetuses of different gestational ages, observed the disappearance of the nephrogenic zone in all fetuses above 35 weeks of gestational age [3].

On the contrary, Faa et al. found the presence of active nephrogenesis up to the 38th week [4]. It appears that in agreement with the data of Rodriguez et al. [5], the nephrogenetic process continues after preterm birth for a period of about 6 weeks; this window decreases further if the neonate develops acute renal injury or if he/she presents a intrauterine growth retardation. Stem cells are present in different parts of the neonatal kidney (Figure 1) [6]. A marked interindividual variability in the number of nephrons has been observed: 6 to 8 glomerular columns were present in late preterm infants (8 columns in Rodriguez' cases), but also in a large number of those up to 23 weeks.

\footnotetext{
* Correspondence: vafanos@tiscali.it

'NICU, Neonatal Pathology, Puericulture Institute and Neonatal Section, AOU and University of Cagliari, Italy

Full list of author information is available at the end of the article
}

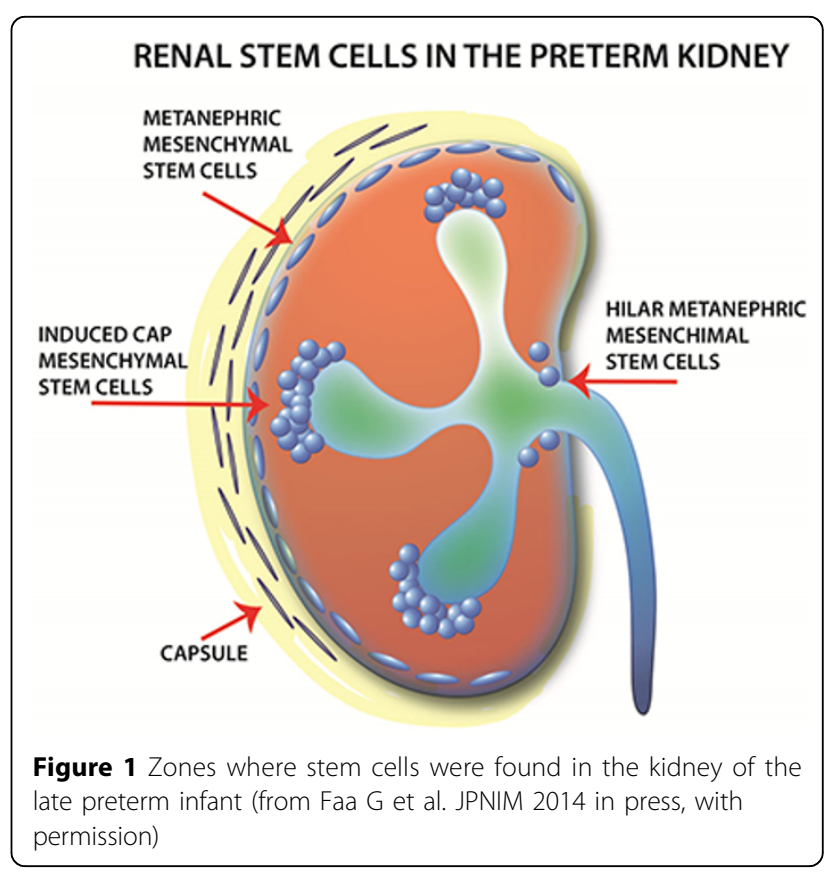

Renal function and pathology in the late preterm Cuzzolin et al. studied 246 preterms divided into 4 groups based on gestational age (one of late preterms): the creatinemia values at birth were similar in the groups, with differences appearing from the 3rd and up to the 21st day of postnatal life $[7,8]$.

No correlation between late preterm birth and the onset of renal pathologies was found shortly after or some time after delivery. This was confirmed by Picone's wide ranging study on 417 late-preterm infants [9].

\section{Authors' details}

${ }^{1} \mathrm{NICU}$, Neonatal Pathology, Puericulture Institute and Neonatal Section, AOU and University of Cagliari, Italy. ${ }^{2}$ Institute of Pathology, AOU and University of Cagliari, Italy. 


\section{References}

1. Faa G, Gerosa C, Fanni D, Monga G, Zaffanello M, Van Eyken P, Fanos V: Morphogenesis and molecular mechanisms involved in human kidney development. J Cell Physiol 2012, 227(3):1257-68.

2. Potter EL, Thierstein ST: Glomerular development in the kidney as an index of fetal maturity. J Pediatr 1943, 22:695-706.

3. Ferraz MLF, dos Santos AM, Cavellani CL, Rossi RC, Correa RRM, dos Reis MA, Teixeira VPA, Castro ECC: Histochemical and immunoistochemical study of the glomerular development in human fetuses. Pediatr Nephrol 2008, 23:257-62.

4. Faa G, Gerosa C, Fanni D, Puddu M, Marinelli V, Zaffanello M, Fanos V: Marked interindividual variability in renal maturation of preterm infants: lessons from autopsy. J Matern Fetal Neonatal Med 2010, 23:129-133.

5. Rodriguez M, Gomez A, Abitbol C, Chandar J, Duara S, Zilleruelo G: Histomorphometric analysis of postnatal glomerulogenesis in extremely preterm infants. Pediatr Dev Pathol 2004, 7:17-25.

6. Fanni D, Gerosa C, Nemolato S, Mocci C, Pichiri G, Coni P, et al: "Physiological" renal regenerating medicine in VLBW preterm infants: could a dream come true? J Matern Fetal Neonatal Med 2012, 25(Suppl 3):41-48.

7. Cuzzolin L, Fanos V, Pinna B, di Marzio M, Perin M, Tramontozzi P, Tonetto $P$, Cataldi L: Postnatal renal function in preterm newborns: a role of diseases, drugs and therapeutic interventions. Ped Nephrol 2006, 21(7):931-938.

8. Puddu M, Cataldi L, Faa G, Yurdakok M, Maringhini S, Fanos V: Perinatal programming: Long-term consequences for the kidney. In Developmental Nephrology: From Embryology to Metabolomics. Elena: Hygeia Press;Fanos V., Chevalier R., Faa G., \& Cataldi L. Quartu S 2011:57-74, Chapter 3.

9. Picone S, Paolillo P: Neonatal outcomes in a population of late-preterm infants. J Matern Fetal Neonatal Med 2010, 23(Suppl 3):116-20.

doi:10.1186/1824-7288-40-S2-A14

Cite this article as: Fanos et al:: The kidney of late preterm infants.

Italian Journal of Pediatrics 2014 40(Suppl 2):A14.

\section{Submit your next manuscript to BioMed Central and take full advantage of:}

- Convenient online submission

- Thorough peer review

- No space constraints or color figure charges

- Immediate publication on acceptance

- Inclusion in PubMed, CAS, Scopus and Google Scholar

- Research which is freely available for redistribution

Submit your manuscript at www.biomedcentral.com/submit 